\title{
An Ecolinguistics Perspectives For English Syllabus Development
}

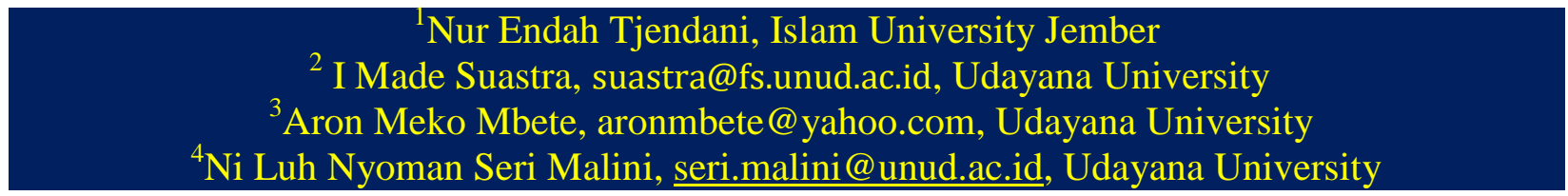

*Corresponding Author: tjendani.endah@gmail.com

Received Date: 10-01-2019 Accepted Date: 28-02-2019 Published Date: 31-07-2019

Abstract-This current study was intended to develop the ecolinguistic perspective-based syllabus. The descriptive qualitative method was applied and natural phenomena were used to develop syllabus. The phenomena focused on to what extent English was mastered by learners and what learning and teaching strategies were applied. The data were obtained through test, questionnaire and direct observation for the need analysis. The State Document related to the curriculum policy was referred to in the situation analysis. The syllabus was developed based on the results of the need analysis and situation analysis and the ecolinguistic perpective-related theories. The contents of the syllabus were developed based on the following elements; they are text, context, linguistic elements, learning situation, teaching and learning activities (Kegiatan Belajar Mengajar, abbreviated to KBM) and evaluation. The content of the text was adjusted to the transactional and interpersonal functions. The context was created based on the inter-, intra-, and trans-cultural contexts of the ecological, social and ideological dimensions. KBM was prepared in accordance with the cognitive linguistic process for the language-related activities and based on the situation chosen by learners for the language production. The outcome of language performance was measured using the performance assessment system, causing the contents of the syllabus to reflect that one element was connected with another in such a way that they formed one integral language meaning.

\section{Keywords: Ecolinguistics, Syllabus, Development}

\section{Introduction}

English language is the first foreign language decided as one of the obligatory subjects taught in junior high school all over Indonesia. The English language learning is aimed at mastering the oral and written active communication (Curriculum 13, 2016), meaning that the learning process focuses on the function and use of the English language in communication. To this end, the efficient and effective learning should be attempted by involving the other disciplines such as linguistics, pedagogic, semiotics, management and so forth. The reason is that learning language is not only intended to investigate language structures but it is also intended to make learners have the knowledge and experience needed to know the quality of relationship within a certain situation. The government has planned and regulated the English language

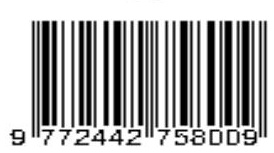


learning in junior high school by issuing a set of regulations which regulate the implementation of the curriculum.

Curriculum 13 is a document issued by the government to regulate the content, learning material, the way of teaching and assessing the learning outcome. In Indonesia the implementation of the curriculum of the English language learning in junior high school has developed highly dynamically. Syllabus contains the regulations used to regulate the curriculum and contains the standard content and the class room learning process. The standard content refers to the linguistic and non-linguistic contents. The standard linguistic content is the form of highly short simple phrases and modalities with clear limitations of meaning which can be used in the daily interactions within families, schools and society.

The environmental domain in which interactions take place is in accordance with the essence of the ecolinguistic perspective which holistically and totally integrates the nonlinguistic and linguistic elements into meaningful units (Haugen, 1972). The knowledge of and the experience in the linguistic and non-linguistic elements which learners have can contribute to the achievement of the meaningful unit. As an illustration, the phenomenon of the meaning of the word blue (biru) and the word green (hijau) used by the Madurese people and the Javanese people who live together in Jember. The word biru means blue and the word hijau means green in the Javanese culture. However, in the Madurese culture the word biru means biru da'un (leaf blue or 'green' in general) and biru langek (sky blue or blue in general). There is no lexical item which means hijau (green) in the Madurese culture. As a result, what is said to be hijau (green) by the Javanese learners is different from what is said to be hijau (green) by the Madurese learners. The Javanese learners might say that blue is blue and that green is green; however, the Madurese learners will say that blue is green (leaf blue) or they might say that blue is blue (sky blue). This will affect the assessment if the assessment technique is used to see that language is defined as a structure of words without paying attention to the local culture where language is used.

The finding of the study conducted by Sabilah (2018) showed that the involvement of the Curriculum 2013-based intercultural English instructions in Public Elementary School Bunulrejo 2 Malang caused the English instructions in primary school to be more meaningful, contextual, and able to improve the learners' communicative competence. The teachers were also made to be 
more creative to select and try out numerous instructional techniques in order to facilitate the learners to feel excited and meaningful to follow the English instructions. The finding of the study conducted by Mulyono (2018) also showed that the learners who suffered from dyslexia was able to communicate using $40.39 \%$ complete independent sentences and $59.61 \%$ incomplete sentences, meaning that everybody can learn language for communication; in other words, someone's level of intelligence does not determine whether he/she can learn language for communication or not. Adnyani (2017) in her study showed that a child can be a bilingual (being able to speak Indonesian and German) through word per word process in the created household situation.

It is clear that learning language does not only mean investigating the language structures but it also means knowing that language cannot be separated from the biological/natural, social, and ideological/cultural environments where language is used in order to acquire the integral meaning. Learning language is a semiotic process within a certain cultural context and text. In language learning the semiotic process is also referred to as cognitive linguistics (Janda, 2010), as learning language means translating, perceiving, interpreting, understanding and using words and cultural symbols without being influenced by how intelligent a learner is. Although the language which is learned is a foreign one, the learning process does not change or separate the learners' connection with their surrounding environment (van Lier, 2004). The cultural context can be found in the surrounding environment, residences, schools, markets, offices and everywhere. The text used to learn a foreign language contains cultural elements in the forms of linguistic forms to be taught as in introducing the lexicon and grammar of the target language. In this case, the lexicon includes every lexical item used to show new knowledge in the target language which is equivalent to that in the local culture. Grammar, in this case, means introducing grammatical elements such as phonemes, morphemes, words, phrases, clauses and discourses containing both the local and target cultures. Therefore, it is important to find out a model ecolinguistic approach to develop the social, cultural and linguistic phenomena-based syllabus.

\section{Theoretical Framework}


Learning language from the ecological point of view is different from learning language from the technological point of view (Tudor, 2003). The ways of learning language from the technological points of view are neatly prepared. They are structured and measurable; they follow the pedagogic principles based on the scenario and the expected learning outcome. However, learners have different learning experiences and ways of learning. They are sometimes confused, find contrasts, and underestimate something during the teaching and learning process. No attention has been paid to this condition in the classroom. The ecological perspective gives more space and time for the teaching and learning interaction based on the pattern of the interaction taking place in society. The learning model of one learner is different from that of another. The important thing is how learners can explore the abilities they have and their ways of learning well and optimally in order to acquire the target language. The condition and situation prepared for learners are adjusted to their ecology. The ecological perspective was applied to the English language syllabus in 2001 in Singapore by Zang (2006). The syllabus was adjusted to the Singaporean ecological condition, namely Singapore is a market place and has many ethnic groups and cultures. The ecological spirit is used in the learning process which is based on the local cultural context, and local and globalized needs. The reason is that language is used as a major means of communication in trade.

Learning language is the domain in which connection can be created. The evidence shows that almost all educational activities need language as a means of communication in which massage is conveyed in every learning interaction. However, the language used for educational purposes is completely different from pedagogy. However, in the language used for educational purposes, linguistics is holistically integrated with pedagogy, leading to a new discipline. Lier (2004:2) more practically refers to it as the ecology of language learning or the trans-disciplinary endeavor (Halliday, 2001, 2014). The development of applied linguistics contributes to the language learning. The two disciplines function in different domains; 1) linguistics theoretically informs the language use and how to learn language which can be really developed at school, and 2) pedagogy gives the theory of learning language more meaningfully; the language function is more relevant to the use and is more interestingly and specifically presented the linguistic diversity. 
Ecology is a discipline which is concerned with the totality of the connectedness between one organism and another within one ecosystem. The ecological perspective considers that different types of people on earth need a balanced connection between them and the nature; therefore, the quality of such a connection should be maintained. It is impossible for someone to live without another and the nature. Therefore, the holistic eco-philosophy emphasizes interconnectedness and interdependence between people and the natural world (Ife, 2013: 46). Ecolinguistics is a part of the ecosystem in the social ecology of linguistic or sociolinguistic studies. Ecology, linguistics and pedagogy cannot be separated from one another in learning language; they form an ecosystem referred to as the ecolinguistic approach which focuses on learning language (van Lier, 2004, 2010; Lwin and Silver, 2014).

More specifically, the ecological approach in learning language is intended to improve, change and maintain the class and school ecology. Teachers and learners are conditioned in such a way that they can maintain the balanced and harmonious connectedness which emphasizes the environment-oriented character building, characterized by the sense of belonging, the goaloriented use of something and ideological transformation (a critical perspective). It is this way of thinking which has inspired the linguistic ecological approach to be developed in the language learning with specific characteristics. According to van Lier (2004, 2010), the ecolinguistic approach contains the following characteristics; they are connectedness, context, patterns/systems, emergence, quality, value, critical, variability, diversity and activity. With reference to the above mentioned characteristics, ecolinguistics considers that the main learning context is within the learners themselves. Therefore, from the view of the theory of ecolinguistic approach, the learning theory refutes the learning dichotomy of skill-getting before skill-using, audilingual and behavioristic and so forth.

From the ecolinguistic perspective, a learner is an integral human being; he/she is not a unit of production of grammar and sentences. The ecolinguistic perspective develops the way of teaching and learning applicable in all situations. It is also a procedure which prepares the learners' involvement and active role as the start. The teaching and learning activity is not a theory or a discontinued system; it is not a teaching method either; it is the whole way of thinking of the teaching and learning complexity; it is a way of viewing language as a tool which can be used for different purposes; and it is a key component to all highly meaningful activities. 
Learners are made to undertake a set of teaching and learning activities which are already prepared; and they are made to be responsible for completing their learning activities with or without teachers, friends and so forth. They are able to find out their way of learning in order to achieve their need for learning as integral human beings.

Naturally, learning language always follows the channel of language structures. According to van Lier (2004:29), language can be traditionally divided into phonology, morphology, syntax, semantics and pragmatics. Language is built up from smaller pieces into bigger pieces, starting with sounds and ending up with texts. Language is composed of the smallest and bigger components, and the acquisition of language is too. The process through which language is acquired is a molecular process; it includes listening, remembering, perceiving, interpreting, using words and sentence structures, making errors and corrections, and so forth until language is completely acquired. It is also stated that human is identical with a dictionary with a number of words 'mental lexicon', which can be called when needed (Baurer, 2003; Booij, 2007; Lieber, 2010). Similarly, language can also be called when needed. From this prospective, one language is different from another; similarly, one variety of a language is also different from another, depending on the social factors such as the situation, the goal of the user and his/her social status, causing one perception of meaning to be different from another. However, such differences can be generalized within the hierarchy of language units (Lier, 2004; Halliday, 2014; Sanford, 2014; Alsagoff and Lick, 2014).The hierarchy of language units easily leads the theory of cognitive linguistics to the process through which a certain language is acquired. It can be explained that learning language can be acquired in accordance with the language hierarchy, meaning that learning language can be acquired through the process of searching out the patterns of language structure system found among languages and cultures (Holme, 2009; Littlemore, 2009; Janda, 2010).

The model dialogu in one culture is different from that in another culture (Bang, Døør, Steffensen \& Nash, 2007, 2012), resulting from the class room ecological condition and the verbal interactional cooperation (English language) between the teacher and leaners who are constructing the performance of certain language skills. Language and communication competence are learned and developed based on the model dialogue within the intra-cultural, inter-cultural and trans-cultural contexts in the biological, social and ideological environments

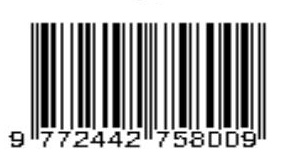


(Gilherme, 2002; Bang \& Døør, 2007). These triple contexts of participation \& language learning are metaphorically relevant to the following three situational prototypes: 1) life within family and with friends as intra-cultural contexts, 2) interacting and negotiating in the market, bureaucracy, democracy, and institution as the inter-cultural contexts, and 3) meeting foreign things/foreigners as the trans-cultural contexts.

It is from this the ecolinguistic approach has been developed to determine the contents of the syllabus which are oriented towards the natural/biological, social and ideological/cultural environments. Syllabus shows the procedure of implementing curriculum. According to the Act number 20 of 2003 concerning the System of National Education, curriculum plans and arranges the contents and learning materials; it is also used as guidance to carrying out the teaching and learning activities. The contents and learning materials refer to the arrangement of the standard learning materials of the subject so that the educational unit can be successfully carried out, which then leads to the achievement of the educational goal. Curriculum contains two aspects; one of which is the planning aspect which is used by the teacher as guidance to carrying out the learning and teaching process. The other aspect is the arrangement of the contents and the manner of carrying out what is planned in order to achieve the educational goal. The procedure of carrying out the two aspects is described in syllabus.

More specifically, syllabus arranges the subject which emphasizes the class level and the level of the contents of the learning material, the method, the role played by the teacher, the role played by learners, and the assessment system. According to Richard (2001:2), syllabus is a specification of the content of a course of instruction and lists what will be taught and tested. It also contains specific language skills, for example, the speaking skill learning. Therefore, it should contain the materials which are trained, starting from the linguistic functions, topic, and the other aspects which are relevant to the learning of speaking. The achievement is assessed based on the norms of the skill. Designing syllabus is a process through which its contents are adjusted to the syllabus applied.

The standard language contents can be found in the language elements which are adjusted to the language hierarchy and its use. As an idicator, the word composition in grammar is an important source of the meaning formation (semogenie). In every language there is a scale of rank (Halliday, 2014:9). As an illustration, English language has morpheme, word, phrase/group 
and clause as one of the lexicogrammatical principles. According to the theory of SFG, a phrase is a group of words and a clause functions as a message; a clause is a transaction of information exchange and it represents what is meant by those involved in the communication (Halliday, 2014: 9). The position of one function of meaning in a clause or sentence is different from that of another function. A sentence has one particular meaning connected by the logico-semantics which contains: 1) the experiential meaning as the interpretation of experience model, 2) the interpersonal meaning needed to create social relationship, 3) the textual meaning needed to create the contextual relevance, and 4) the logical meaning needed to develop the logical relationship.

The first step which should be taken in order to produce syllabus more effectively and efficiently is analyzing the need and situation. The objectives of the need analysis, as adapted from Richard (2001: 52) are as follows:

1) Identifying the domain of the linguistic capability and the domain of the non-linguistic capability already acquired;

2) Identifying the gap between the capability of one learner and that of another;

3) Collecting information on the studying strategy and the problem faced;

4) Knowing what is expected by learners and stakeholders from English language;

5) Determining the aspect of the learning culture and the context of topic selected.

The analysis of situation is based on the document of the English language learning policy used to complete the real data used as guidance to the evaluation of the minimum achievement target. The goals of the situation analysis adapted from Richard (2001: 93-102) are as follows:

1) Knowing what level of English language which should be mastered by learners;

2) Finding out what learning method which should be applied;

3) Identifying what approach should be used to prepare syllabus, curriculum and learning material;

4) Identifying whether the learning process reflects the specific learners' cultural context, and

5) Determining the development of the learning source which can be used, and the direction of the innovation needed. 
Syllabus prepares different types of stages of activities needed to implement the ecolinguistic approach. The syllabus contents include the goal, the text, the context, the language elements, the learning method/process using the figure of speech, and evaluation.

\section{Method}

This current study is descriptive qualitative in nature using the natural phenomena for developing the ecological perspective-based syllabus. The phenomena focus on the planning, process and the practical and conceptual learning outcome of English language in junior high school. The data of the study were obtained through the identification of the learners' linguistic and non-linguistic mastery, the topic chosen by the learners and an interview in which the interviewees were the stakeholders about the implementation of the current syllabus. The procedure of the phonological research made the researcher investigate a number of subjects by being directly involved in the development of the patterns and connectedness of meaning taking place. The study was carried out based on the practical condition-based primary data and the secondary data taken from the documents related to the principles of the English language syllabus.

\section{Findings and Discussion}

\subsection{Need Analysis}

The need analysis is intended to identify the linguistic and non-linguistic phenomena in the real condition in which the process of English language in junior high school is implemented. It should be carried out and achieved based on the achievement of competence described in syllabus. The phenomenon was based on the outcome of the initial test, what was observed from the teaching and learning process and the questionnaire through which the topic chosen by learners was mentioned, and the learners' strategy of learning English language. The need analysis was categorized based on the sequence of the data obtained and analyzed based on each function.

\subsubsection{The Linguistic and Non-linguistic Mastery Based on the Initial Test Outcome}

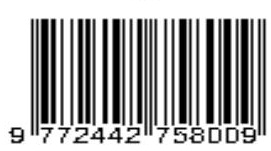


The test instrument used as the technique for obtaining the data on the learners' competence was a test consisting of free writing, filling gap, and synonym or paraphrase. All the test items were made by the researcher and were discussed with the class teacher. The test analysis focused on the learners' capability in using lexicon and grammar (as the linguistic elements) and the learners' knowledge of and experience in a certain context (the non-linguistic elements) affected by the ecolinguistic condition. The following data illustrates the material of analysis.

Test item $\rightarrow$ Danny is truthful and never cheat or steal, he is a ... boy.

The options of the answer $\rightarrow$ honest; shy; good; loyal; kind.

The test item had three adjectives; they were truthful, cheat and steal. In the options of the answer given by the learners, there were five adjectives; they were honest; shy; good; loyal; kind. The answer given by the learners contained the social context, which can be illustrated as follows.

1) They were embarrassed; therefore, they did not cheat.

2) They were honest; therefore, they could be trusted,

3) They never stole or cheat; therefore, they were kind

4) They could be trusted; therefore, they were kind and faithful.

5) The answer loyal (faithful) might be connected with truthful $\rightarrow$ (trustable)

The learners had been familiar with the lexical item honest (read hones), as the correct answer based on the key prepared by the teacher) through songs and current vocabulary of the teenagers. However, the answers given varied based on the context understood by the learners. Among 64 learners, 10 answered honest. The same thing also took place in the following test item and its answer.

Test item $\rightarrow$ I like to make people laugh. I am ...

The options of the answer $\rightarrow$ funny; clown

The test item shows the phrase to make people laugh (causing people to laugh), which was used within a funny context and caused people to laugh (clown). The words funny and clown were the answers given by the learners. However, none used the word humorous (the key prepared by the teacher) as the correct answer, although it was a popular word among the learners. None chose

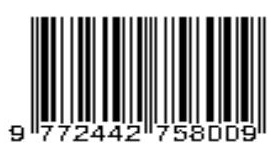


the word comedian as the alternative answer either. The answer given by the learners were in accordance with their ecolinguistic context (van Lier, 2004).

The data on the learners' capability in English language were taken from the texts written by the learners, as illustrated below.

Text $1 \rightarrow \underline{\text { Im }}$ is student in SMP 1 Jember. I born 14 years.

Text $2 \rightarrow$ My school in SMP 1 Jember. I like play game and basketball. I am go to school at bus Text $3 \rightarrow$ I like listens music and read novel. I like listens music english. I usually listens music in evening. And reading love novel before have dinner.

Text $4 \rightarrow$ She is clever because my niece imitate my sister, ... Niece is an interesting person.

As can be seen in the above data, the ideas written by the learners were inspired by their experiences. The noun phrase (NP), verb phrase (VP) and adjective phrase (AP) used by the learners in every sentence varied. Some were correct and some were incorrect, resulting from the first language they had acquired. Specifically, it is not difficult to understand the NP pattern which functions as the subject of a sentence such as the proper name (Isa), the first person singular (I), the second person pronoun (you), and the plural third person pronoun (they) and the singular third person (he, she). In fact, the above data show that the learners' knowledge of NP used as the subject was good enough, but their knowledge of NP used as the object was still poor, as simplified by my and family, food meat ball, music English, the cat 3, and so forth. The same problem could also be found in the VP used as the predicate. Their knowledge of whether to use a singular verb or a plural verb, whether to use verb with to infinitive or not, and whether to use to infinitive be or gerund is still poor, as exemplified by the following phrases: I am go, like listens, play bike around, Im is, My school in SMP, I likes and so forth. They still wrongly placed the adjective and adverb of place used attributively. The attributively used adjective which should have been placed prior to the noun the predicatively used adjective which should have been placed after the verb to modify the subject were improperly placed, as exemplified by trip very long, sleep more formally, He favorit food, the cat the poor and so forth. The above data show that learning the target language cannot be separated from the learners' experiences and knowledge of the text written within their surrounding language and cultural context (Chomsky, 2002). This can be identified from how the learners wrote their ideas in the form of phrases. From the point of view of communication competence, it can be stated that the learners could not

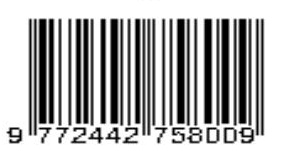


differentiate noun as subject, verb as predicate and adjective as modifier, leading to semigrammaticalization (Halliday, 2014: 67) and to the system of logical-semantic relations (Halliday, 2014: 63). The linguistic and non-linguistic knowledge of the learners contributed to the target language acquiring process.

\subsubsection{The Teaching and Learning Process in the Classroom}

The teaching and learning activities were observed, and the result of the observation was written in the form of an article entitled Classroom Talk as a Classroom Management Practice at Junior High School, which was published in the proceeding of The $6^{\text {th }}$ International Conference Educational Management Administration and Leadership (ICEMAL). The result of the observation showed that RPP prepared by the teacher based on curriculum 13 was not well implemented in the classroom (Tjendani, 2016: 246-250). The result also showed 1) the learning initiative often came from the teacher using display and choice of question or short answer questions, causing the learners to respond by reading their notes or books or short answers uttered together; 2) the evaluation was made based on the test items in the book and LKS; 3) the teaching and learning activities followed the design of the learning material, causing the opportunities which the learners had to explore using the target language to be highly limited; 4) the learners had many opportunities to do the test items and to answer questions. When the teacher justified the answer given by one learner, the others did the same thing, and limited feedback was also provided.

\subsubsection{The Topic Chosen by the Learners}

The choice of the topic made by the learners was intended to identify and involve them in the selection of the topics; what topics would be highly useful, what topics would be useful, and what topics would be useless. The situations which were prepared totaled 30 . The topics were prepared based on the text and context described in Curriculum 13 which suit the English language learning for the students of the $7^{\text {th }}$ grade of junior high school. The text and context were made to be connected with environment and three prototypes of dialogue situation from the ecolinguistic perspective; they are intra-cultural, inter-cultural, and trans-cultural, which were adjusted to the natural, social and cultural environments of the Pendalungan society in Jember.

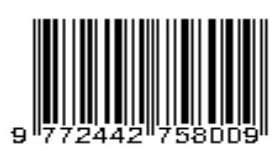


The data showed that $45 \%$ of the learners chose 10 highly useful topics, $35 \%$ chose 15 useful topics, and 20\% chose useless topics. The complete data are presented in Table 1 below.

Table 1

The Topics Chosen by the Learners

\begin{tabular}{|c|c|c|}
\hline $\begin{array}{l}\text { The highly useful topics chosen } \\
\text { by } 45 \% \text { of } 64 \text { learners }\end{array}$ & $\begin{array}{c}\text { The useful topics chosen by } \\
35 \% \text { of } 64 \text { learners }\end{array}$ & $\begin{array}{c}\text { The useless topics chosen by } \\
20 \% \text { of } 64 \text { students }\end{array}$ \\
\hline $\begin{array}{l}1 \text { getting to know you } \\
3 \text { school yard } \\
\text { environment } \\
4 \text { classroom activities } \\
7 \text { joining hobby or } \\
\text { Interest group } \\
12 \text { watching TV, what } \\
\text { program; } \\
15 \text { inviting friends for } \\
\text { party } \\
16 \text { gardening } \\
22 \text { buying things at the } \\
\text { market } \\
25 \text { camping } \\
29 \text { electing class committee }\end{array}$ & $\begin{array}{l}5 \text { classroom environment } \\
6 \text { playing sports, what } \\
\text { sports; basket } \\
8 \text { talking to neighbors } \\
24 \text { taking public } \\
\text { transportation } \\
9 \text { talking activities at } \\
\text { home } \\
10 \text { cooking at the kitchen } \\
13 \text { watching film/cinema } \\
14 \text { listening to music, } \\
\text { what music } \\
17 \text { farm animal } \\
18 \text { going to zoo } \\
19 \text { visiting beach } \\
21 \text { harvesting rice or corn or } \\
\text { fruit } \\
23 \text { buying things at stores or } \\
\text { supermarket } \\
25 \text { camping } \\
30 \text { visiting bank }\end{array}$ & $\begin{array}{l}2 \text { talking to friends } \\
11 \text { touring a house } \\
20 \text { visiting coffee or } \\
\text { coco plantation } \\
26 \text { visiting Kelurahan } \\
\text { Office } \\
27 \text { how to be MC } \\
\text { (Master Ceremony) } \\
28 \text { OSIS meeting }\end{array}$ \\
\hline
\end{tabular}

What was interesting to be observed was that the plant-related topics, such as gardening became a highly useful topic, however, the topic harvesting rice or corn or fruit became a useful one, and the topics visiting coffee or coco plantation because the useless ones. In Jember Regency there are many coffee and coco plantations, some of which are used as the plantation tourist destinations. The topic getting to know you became a highly useful one, and the topic talking to friends became a useless one, although, the fact showed that the learners often talked to their fellows. The reason was that, from the local cultural context point of view, talking to friends implies 'gibah', namely the habit of talking about the negative things of someone else.

\subsubsection{The Learners' English Language Learning Strategy}


The questionnaire distributed to the learners contained the language learning activities such as taking note, paying attention to the teacher, using new vocabulary when communicating and discussing things with friends, re-reading what was written, correcting grammar, using punctuation marks, re-checking the vocabulary used, and so forth. The score ranged from 1 to 5; each reflected the activity being done while studying English language and the learners were supposed to circle the answer chosen.

The result of the questionnaire showed that $11 \%$ of the learners usually did not do any language learning activities; $76.5 \%$ seldom did language learning activities; $12.5 \%$ usually did language learning activities, and none showed that they had never and always done language learning activities. What was interesting to be observed was that $76.5 \%$ of the learners seldom did English language learning activities such as taking note, asking the teacher, reading prior to doing test items, making sentences using new vocabulary, consulting references, discussing with friends, doing homework, trying to make sentences using new vocabulary, and interpreting the sentence meaning. The data showed that the learners had not been accustomed to doing specific language learning activities. Most time was spent doing the test items in the text book used in the classroom.

\subsection{The Situation Analysis}

This sub-part presents the data on the Permendikbud (the Regulation Issued by the Minister of Education and Culture) No. 64 of 2016 concerning the Standard Contents, Permendikbud (the Regulation Issued by the Minister of Education and Culture) No. 65 of 2016 concerning the Standard Process, Curriculum 2013 and the Syllabus of the English Language Subject for Junior High School. The standard content is intended to limit the material scope in order to achieve competence in four dimensions; they are the spiritual attitude, the social attitude, knowledge and skill. The material scope of the English language text and context required effective interaction in the environment, family, school, society, nation, state and regional areas. The text used short and simple phrases and modalities as the linguistic elements with clear-cut meaning in functional, interpersonal and transactional discourses, and the types of the text were recount, announcement, narrative, descriptive and song. 
A process was needed to achieve the content competence mentioned above. The standard process refers to the criteria which should be fulfilled in the implementation of the learning process in order to achieve the standard passing competence. The process through which the scientific approach was applied was strengthened by the discovery/inquiry learning-based thematic in order to produce the problem solving-based work (the project-based learning). The learning process was assessed using the authentic assessment, the result of the learning process was evaluated using the oral and written test during the learning process and when the lesson unit was completed.

Curriculum is needed to realize the standard content and process. Currently, the English language learning applies Curriculum 2013 containing the learning objective and real competence intended to be achieved. The objective of the English language learning is to master the competence in the written and oral active communication using the text which is accurate and acceptable to the context of daily life in the household, school, and society environments. The text mastery includes the social function and structure of the text and the linguistic elements chosen based on the objective of the context of the functional communication; therefore, the types of the text are descriptive, recount, narrative, procedure and factual report. The language skills include listening, speaking, reading and writing. The syllabus more specifically arranging the learning process is needed to realize the curriculum.

Table 2 presents the syllabus of English language for junior high school as the realization of the curriculum.

The Curriculum 2013-based Syllabus of English Language (The Ministry of Education and Culture, 2016)

\begin{tabular}{|c|c|c|c|c|}
\hline Text & Context & $\begin{array}{l}\text { Linguistic } \\
\text { Elements }\end{array}$ & $\begin{array}{c}\text { Topic of the } \\
\text { Learning } \\
\text { Material }\end{array}$ & $\begin{array}{c}\text { Learning } \\
\text { Process }\end{array}$ \\
\hline Interpersonal & $\begin{array}{l}\text { Meeting other } \\
\text { people }\end{array}$ & $\begin{array}{l}\text { Greeting, farewell, } \\
\text { thanking, } \\
\text { apologizing and } \\
\text { responding }\end{array}$ & $\begin{array}{ll}1 . & \text { How are } \\
\text { you? } & \\
2 . & \text { It's me }\end{array}$ & \multirow{2}{*}{$\begin{array}{l}\text { Scientific: } \\
\text { Observing, } \\
\text { asking, } \\
\text { collecting } \\
\text { information, } \\
\text { negotiating } \\
\text { and } \\
\text { communicatin } \\
\text { g }\end{array}$} \\
\hline Transactional & $\begin{array}{l}\text { Self-identity, } \\
\text { telling time, } \\
\text { animals, } \\
\text { human, non- } \\
\text { human, and the }\end{array}$ & 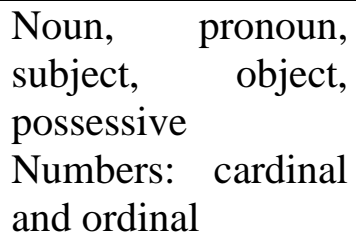 & $\begin{array}{l}3 . \quad \text { It's } \text { my } \\
\text { birthday } \\
\text { 4. I love } \\
\text { people around } \\
\text { me }\end{array}$ & \\
\hline
\end{tabular}




\begin{tabular}{|l|l|l|l|l|}
\hline & $\begin{array}{l}\text { buildings } \\
\text { around } \\
\text { learners } \\
\text { (characteristic } \\
\text { and action) }\end{array}$ & $\begin{array}{l}\text { Articles, plural and } \\
\text { singular } \\
\text { Declarative, } \\
\text { negative, } \\
\text { interrogative, } \\
\text { simple present } \\
\text { tense, prepositions }\end{array}$ & $\begin{array}{l}\text { How pets do } \\
\text { you have }\end{array}$ & \\
\hline Functional & $\begin{array}{l}\text { Life of young } \\
\text { people, } \\
\text { animals, } \\
\text { human, non- } \\
\text { human and the } \\
\text { building } \\
\text { around the } \\
\text { learners } \\
\text { characteristics, } \\
\text { taste, mentality, } \\
\text { psychology/feeling, } \\
\text { intelligence } \\
\text { Demonstrative } \\
\text { pronouns } \\
\text { Punctuation marks } \\
\text { Song } \\
\text { Description }\end{array}$ & $\begin{array}{l}\text { me } \\
\text { things }\end{array}$ & \\
\hline
\end{tabular}

Based on the syllabus above, the English language learning is carried out based on RPP prepared for one meeting in the first semester of grade 7, which, if added together, totals 36 teaching hours.

The results of the need and situation analysis show that learners need more real and meaningful situation and condition, and need to focus on the linguistic and non-linguistic elements which are not so different from their personal experiences and knowledge. The method used to teach in the classroom refers to the activities described in the book prepared by the teacher. One element of the syllabus used as the guidance to the implementation of Curriculum 2013, in so far as the text, context and linguistic components are concerned, overlaps with another. As an illustration, the transactional text and functional text have the same context. In addition, the linguistic elements badly focus on the specific grammar needed for a specific use. Then, what is important is involving learners to be able to develop their learning potentials to develop the syllabus of English language. To this end, learners, as the main context of those who are learning something (van Lier, 2004, 2010), should be viewed as integral persons who are able to think and do the language activities to produce language through the cognitive linguistic process. It is this which requires that syllabus should be prepared using the ecolinguistic perspective. 


\subsection{The Formulation of the Ecolinguistic Perspective-based Syllabus}

A syllabus describes the main elements which will be used to plan the learning process and to prepare the focus and the main contents of the language learning. The model syllabus used in the current study is adapted from the task-based syllabus (Krahnke, 1987, Richard, 2002), Brinton et. al., 2011) and is adjusted to the ecolinguistic approach-based model syllabus. The elements of the linguistic contents were chosen and sorted based on the theory of SFG, in so far as the phrase and clause use is concerned. The important elements of syllabus describe the learning objective, the content selection, the determination of the domain/scope and its parts, how the classroom learning is formulated, and the assessment system.

The learning objective is principally adapted from the different viewpoints among the linguistic norms, learning norms, and policy and curriculum. In addition, the ideology of the learning objective also takes what needs to be currently learned and what needs to be learned by learners in the future, socio-cultural pluralism, and the learner-centeredness (van Lier, 2004; Richards, 2001). The general objective is directly adopted from the curriculum, and the specific objective of the syllabus of the English language learning for the first semester of grade 1 is adopted from the result of research.

The learning objective which the syllabus contains is adapted to the result of the need and situation analysis, the reflection of the ideology of the ecolinguistic approach and the theory of SFG for the following reasons:

1) The results of the need and situation analysis really reflect how competent learners in communication are, their learning strategy, and the teaching and learning activities as the implementation of the curriculum policy,

2) The ecolinguistic approach is used to divide the learning text and context which show the competence in specific communication in the form of model dialogues (Bang, Døør, Steffensen $\&$ Nash, 2007, 2012).

3) The language learning process is based on the hierarchy of language units (van Lier, 1995 2004) by applying the linguistic cognitive process (Holme, 2009; Littlemore, 2009; Janda, 2010), formulated in every learning activity through the process of perceiving, interpreting, comprehending, using, mastering and vice versa. 
4) The language units are classified in an integrated manner, and are explained in the clausal metafunction, namely clause as a message, clause as an exchange, and clause as a representation (Halliday, 2014:83); a phrase is defined as a group of words.

5) The achievement of communication competence can be clearly seen from the stages in the process and can be directly assessed using the performance assessment(O’Malley, 1996; Stecher, 2010, Palm, 2008).

6) The result of the FGD evaluation was made by the English teachers, who are the MGMP members and give emphasis on the more specific competence needed to contribute to the formation of the nation's character.

\section{The Formulation of the Ecolinguistic Perspective-based Syllabus}

\section{a. General Objective}

In general, the objective of the English language learning for grade 1 of junior high school is adapting Curriculum 13 in which the communication competence is still maintained as the target. It is intended to develop the potentials which learners have to communicate competently in the transactional and interpersonal discourses using different types of oral and written texts containing phrases and independent clauses and modalities to implant the great values of the nation character within the context of daily life in the biological, social, ideological, family, school and societal environments to face the globalization era.

\section{b. Specific Objectives}

Specifically, the English language learning is intended to allow learners to have the communication competence required to:

1) develop the behavior of becoming patriots by bequeathing the nation's ideological and cultural values in the forms of simple visual and verbal texts to make them prepared to face the cultural changes effectively and efficiently,

2) make learners able to communicate orally and in writing effectively and to use the four language skills (listening, reading, writing, speaking) for creating daily relationship with their environment, families, friends and societies based on the norms with different forms of texts contain using phrasal structures and independent clauses,

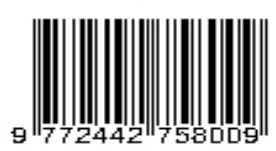


3) make decisions individually and collectively through which the learning objectives are formulated and the development of the achievement of the learning activities is measured using the performance assessment system; in this way, they are supposed to be able to develop their learning responsibility and learning strategy (self-independence learning and selfresponsibility learning),

4) to make learners acquire digital literacy needed to develop their learning skills based on their goals.

Based on what was described above, the ecolinguistic perspective-based syllabus is formulated and developed as presented in Table 3 below:

Table 3

Model Ecolinguistic Perspective-based Syllabus

\begin{tabular}{|c|c|c|c|c|c|}
\hline Text & Context & $\begin{array}{l}\text { Linguistic } \\
\text { Elements }\end{array}$ & $\begin{array}{c}\text { Learning } \\
\text { Material/Topic }\end{array}$ & $\begin{array}{c}\text { Learning } \\
\text { Process }\end{array}$ & Evaluation \\
\hline Interpersonal & $\begin{array}{l}\text { Intra-cultural } \\
\text { contexts: } \\
\text { families, } \\
\text { friends and } \\
\text { teachers }\end{array}$ & $\begin{array}{l}\text { Simple } \\
\text { phrases: noun } \\
\text { phrase, } \\
\text { adjective } \\
\text { phrase and } \\
\text { verb phrase } \\
\text { independent } \\
\text { clauses: } \\
\text { independent } \\
\text { sentences }\end{array}$ & $\begin{array}{l}\begin{array}{l}\text { Getting to } \\
\text { know one } \\
\text { another }\end{array} \\
\text { Schooling } \\
\text { and housing } \\
\text { Celebrations } \\
\text { and rituals } \\
\text { Shopping } \\
\text { Environment } \\
\text { Camping }\end{array}$ & $\begin{array}{l}\text { Cognitive } \\
\text { linguistics in } \\
\text { language } \\
\text { learning } \\
\text { Sound/word } \\
\text { perception, } \\
\text { interpretation, } \\
\text { comprehension, } \\
\text { use, } \\
\text { acquisition }\end{array}$ & $\begin{array}{l}\text { Performance } \\
\text { assessment: } \\
\text { checklist, } \\
\text { analytic } \\
\text { rubric and } \\
\text { holistic }\end{array}$ \\
\hline Transactional & $\begin{array}{l}\text { Inter-cultural } \\
\text { contexts: } \\
\text { authority } \\
\text { relations } \\
\text { (market, zoo, } \\
\text { school, } \\
\text { calendar etc. } \\
\text { Trans- } \\
\text { cultural } \\
\text { contexts: }\end{array}$ & $\begin{array}{l}\text { Text types: } \\
\text { descriptive } \\
\text { and } \\
\text { procedural } \\
\text { Vocabulary: } \\
\text { 1,000 words } \\
\text { Grammar: } \\
\text { Verb } \\
\text { expressions; } \\
\text { tenses }\end{array}$ & & & \\
\hline
\end{tabular}




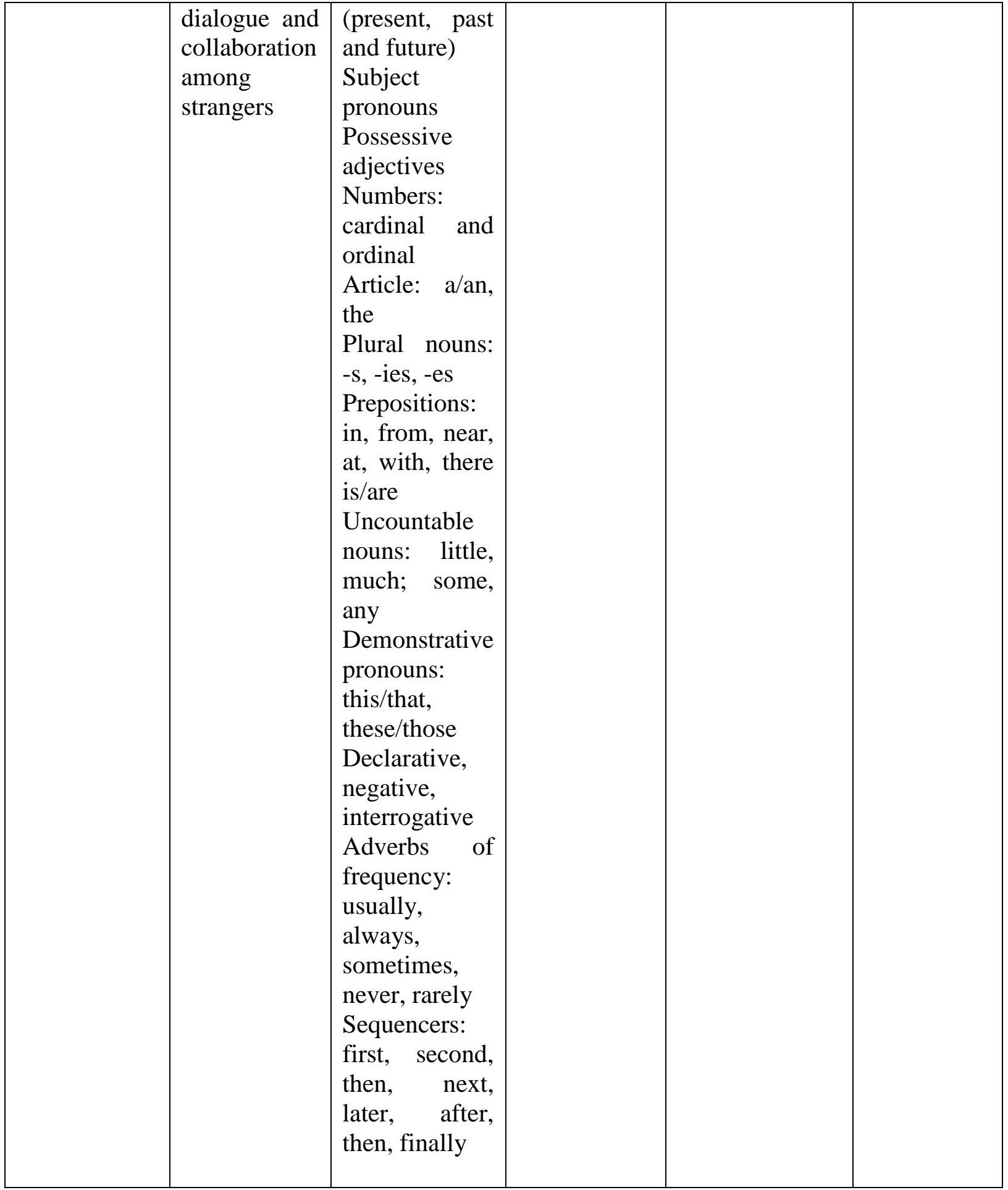

The topics chosen by learners are specifically developed in the sub-topics by taking the following things into consideration. 
Topic: Getting to know one another (present tense and personal pronoun)

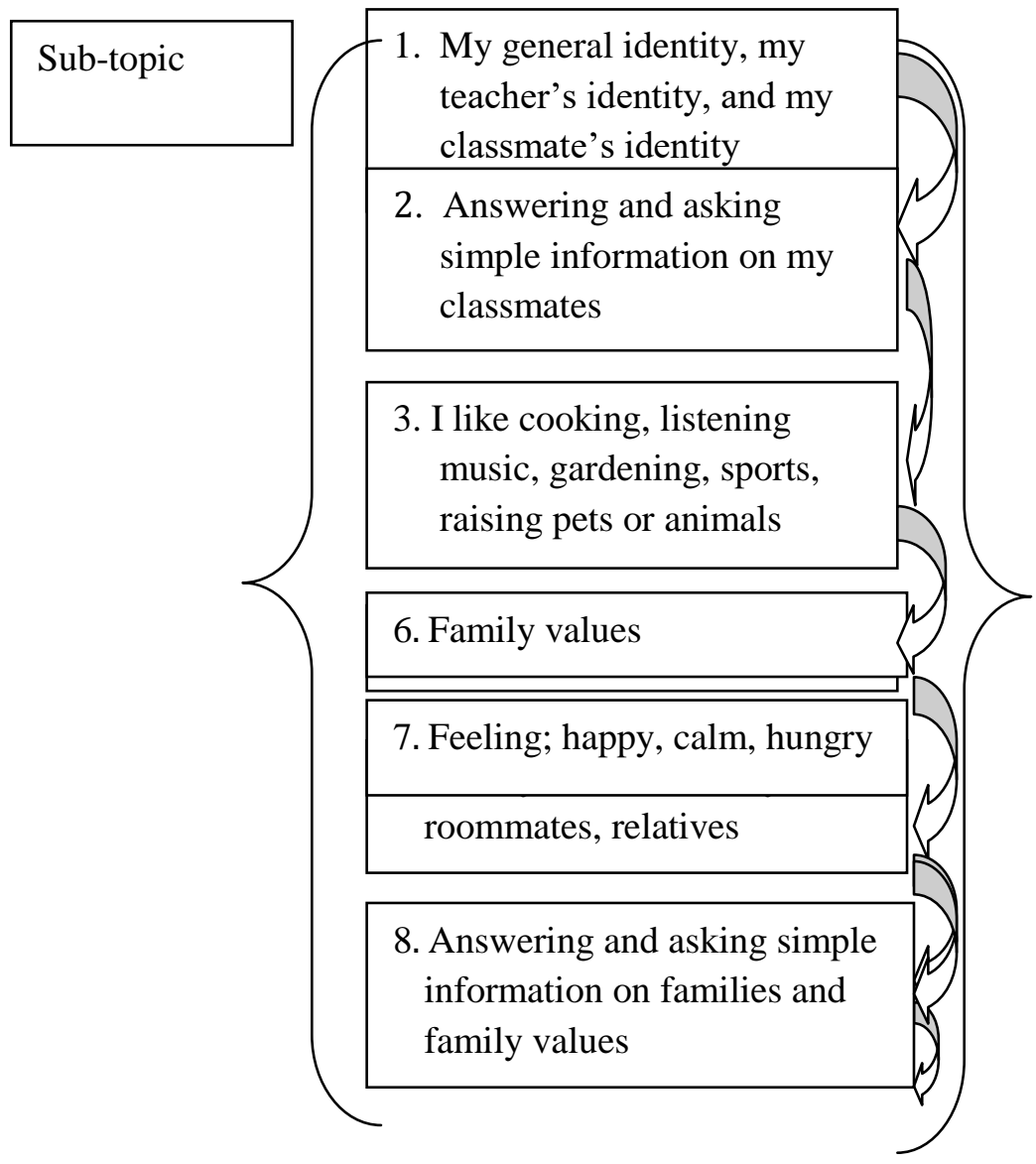

It can be explained that sub-topic 1 to sub-topic 8 cannot be separated from one another in Getting to know one another. The situation created starts from knowing the English language teacher and is continued to knowing the teachers teaching the other subjects, knowing oneself and classmates, and so forth. It is clear that one sub-topic is made to be connected to the others in the text and English language learning context from the time when the syllabus is prepared. From the ecophilosophical point of view, the holistic eco-philosophy emphasizes the interconnectedness and interdependence between people and the world (Ife, 2013: 46). The animate and non-animate things are connected with one another to create a harmonious and quality life. It is this which connects syllabus, as a non-animate thing, with the situation and condition in which the class ecology, as an animate thing, can be made to be alive. 
The cognitive linguistic learning process can be presented in detail in table 3 below.

Table 3

The Cognitive Linguistic Learning Process

\begin{tabular}{|l|l|}
\hline \multicolumn{1}{|c|}{ Stage } & \multicolumn{1}{c|}{ Activity } \\
\hline Perceiving & $\begin{array}{l}\text { The teacher creates the learners perception of the situation of the } \\
\text { language context and text that will be biologically, ideologically, and } \\
\text { sociolinguistically discussed. }\end{array}$ \\
\hline Interpreting & $\begin{array}{l}\text { Presenting the new learning material by reading it either silently or } \\
\text { loudly to create the interpretation of the language used in the next } \\
\text { learning skill }\end{array}$ \\
\hline Understanding/Using & $\begin{array}{l}\text { The learners interpretation is referred to in the learning material } \\
\text { activity to gain what can be understood of the text and context of the } \\
\text { target language which can be used in every learning activity which can } \\
\text { show the competence in the oral and written communication based on } \\
\text { the activities described in the learning material (trial and error) }\end{array}$ \\
\hline Mastering & $\begin{array}{l}\text { The extent to which any material is mastered can be identified from } \\
\text { the metacognitive activities in written and oral forms (writing and } \\
\text { speaking) based on the target language skills described in the } \\
\text { assessment description, }\end{array}$ \\
\hline Closing & $\begin{array}{l}\text { The learners' learning outcome is checked using the description of } \\
\text { performance already prepared; it can be checked by the teacher } \\
\text { him/herself, a colleague or another teacher. Feedback is given }\end{array}$ \\
\hline
\end{tabular}

That is the syllabus formulated based on the results of need analysis, situation analysis, ecolinguistic perspective, and the theory of SFG. A language can be acquired based on the language hierarchy-based process through which a language system used to express certain meaning between language and culture can be found (Lier, 2004; Holme, 2009; Littlemore, 2009; Janda, 2010). Everybody undergoes the same language learning semiotic cognitive process which includes perceiving words, using, mastering and acquiring the target language. Perceiving words can start from listening to and reading words before associating them in such a way that they will become meaningful.

\section{Conclusion}

The development of the ecolinguistic perspective-based syllabus is the result of need analysis, situation analysis and the ecolinguistic-related theories for language learning purposes. Text, context, language, learning situation, learning process and assessment are the elements which cannot be separated from the implementation of the curriculum. The elements 
used are based on those needed for formulating the syllabus. Such elements contain the content of the language activity and the language production based on the ecolinguistic theories.

The language function-based content of the text takes the model dialogue integrating the natural, social and ideological dimensions with the inter-cultural, intra-cultural and trans-cultural contexts into consideration. The language elements are adjusted to the meaning which the phrases and clauses contain, and the learning situation is adjusted to the topic chosen by learners. The teaching and learning process is adjusted to the learning process based on the cognitive linguistic process. Finally, assessment is made based on the language performance achieved and the language production made by learners, referred to as the performance assessment.

\section{References}

Alsagoff, Lubna, and Ho CheeLick. 2014. What is the Structure of Language?. In Language in Education Sosial Implications, edited by Rita Elaine Silver and Soe Marlar Lwin, 1765. Bloomsbury, London.

Brumfit, Christopher. 1984. Communicative Methodology in Language Teaching, the roles of Fluency and Accuracy. Cambridge University Press. Cambridge

Brown. 2005. Testing in Language Programs; a Comprehensive Guide to English Language Assessment. Mc Graw Hill

Booij, Geert. 2007. The Grammar of Words, An Introduction to Morphology. Oxford University Press. Great Britain

Bundsgaard, Jeppe. Et.all. 2012. Communicative Competences and Language Learning in an Ecological Perspective: the Triple ontexts of Participation and Language Learning from Childhood to Adulthood. Critical Literacy: Theories and Practices 6:1 2012, page $46-58$

Chomsky, Noam. 2000. New Horizon in the Study of Language and Mind. Cambridge Unversity Press. UK

Holme, Randal. 2007. Cognitive Linguistics and Language Teaching. CPI Antony Rowe, Chippenham and Eastbourne. Great Britain.

Harmer, Jeremy. 2010. The Practice of English Language Teaching. Pearson Longman. British.

Halliday, M.A.K. 2014. Functional Grammar. Routledge. New York.

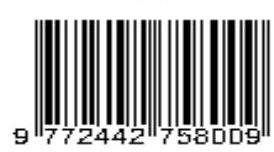


Ife, Jim. 2013. Community Development in an Uncertain World, vision, analysis and practice. Cambridge University Press.

Janda, Laura A. 2010. From Cognitive Linguistics to Cultural Linguistics. University of North Carolina and University of Troms $\varnothing$

Krahnke. 1987. Approaches to Syllabus Design for Foreign Language Teaching. Printice Hall Regents, Englewood Cliffs.

Kemendikbud. 2016. Permendikbud No. 64 tahun 2016 tentang Standar Isi Pendidikan Dasar dan Menengah. Pusat Kurikulum dan Perbukuan. Balitbang. Jakarta.

Kemendikbud. 2016. Permendikbud No. 65 tahun 2016 tentang Standar Proses Pendidikan Dasar dan Menengah. Pusat Kurikulum dan Perbukuan. Balitbang. Jakarta.

Kemendikbud. 2016. Silabus Bahasa Inggris untuk SMP. Pusat Kurikulum dan Perbukuan. Balitbang. Jakarta.

Lier, Leo Van. 2004. The Ecology and Semiotics of Language Learning. A Sociocultural Perspective. Kluwer Academis Publishers. Borton.

Lier, L. Van. 2010. The Ecology of Language Learning: Practice to Theory Theory to Practice. Procedia - Social and Behavioral Sciences, 3 (2-6), 1276-1284, doi:10.1016j. sbpro. 2010.07.005

https://books.google.co.id/books?id=HkqSCgAAQBAJ\&pg=PA84\&lpg=PA84\&dq= procedia+social+and+behavioral+sciences $+3+(2010)+2-$ $\underline{6 \& \text { source }=\text { bl\&ots }=\text { adqF9vVhCi\&sig }=\mathrm{HXeVp}}$

Littlemore, Jeannette. 2009. Applying Cognitive Linguistics to Second Language Learning and Teaching. CPI Antony Rowe, Chippenham and Eastbourne. Great Britain.

Larsen-Freeman, Diane. 2011. Key Concepts in Language Learning and Language Education. In The Routledge Handbook of Applied Linguistics, edited by James Simpson, 155-170. Routledge. New York. USA.

Lwin, Soe Marlar and Rita Elaine Silver. 2014. What is the Role of Language in Education. In Language in Education Sosial Implications, edited by Rita Elaine Silver and Soe Marlar Lwin, 1-18. Bloomsbury, London.

Mulyono et al. 10.24843 The Variation of Sentence Structure in the Dyslexic Children's Speech. e-Journal of Linguistics, [S.1.], p. 118-134, july 2018. ISSN 2442-7586. Available at: <https://ojs.unud.ac.id/index.php/eol/article/view/40701>. Date accessed: 19 dec. 2018. doi: https://doi.org/10.24843/eJL.2018.v12.i02.p.04

Nunan, David. 2004. Task-based Language Teaching. Cambridge University Press. Cambridge. 
O’Malley and Pierce. 1995. Authentic Assessment for English Language Learners. Longman

Palm, T. (2008). Performance Assessment and Authentic Assessment: A conceptual Analysis of the Literature. Practical Assessment, Research \& Evaluation, 13 (4). Retrieved August 31, 2009, from http://pareonline.net/getvn.asp?v=13\&n=4

Raharjdo, Christanto. 2016. Pendalungan : Sebuah 'Periuk Besar' Masyarakat Multikultural .Fakultas Ilmu Budaya. Universitas Jember. http://wa-iki.blogspot,co.id/2013/08/pendalungan-sebuah-periuk-besar.html

Richards, Jack. 2001. Curriculum Development in Language Teaching. Cambridge University Press

Richards, Jack and Renendya. 2002. Methodology in language Teaching; an Anthology of Current Practice. Cambridge University Press

SABILAH, Fardini et al. Designing the Intercultural Teaching Using "Dialogic Reading" Strategies for the English Students at Primary Schools. e-Journal of Linguistics, [S.I.], p. 1-14, jan. 2018. ISSN 2442-7586. Available at: <https://ojs.unud.ac.id/index.php/eol/article/view/36221>. Date accessed: 19 dec. 2018

SRI ADNYANI, Ni Luh Putu et al. Early Lexical Development and the Development of Translation Equivalents in a Simultaneous Bilingual Child. e-Journal of Linguistics, [S.I.], p. 130-148, july 2017. ISSN 2442-7586. Available at: <https://ojs.unud.ac.id/index.php/eol/article/view/34687> . Date accessed: 19 dec. 2018. doi: https://doi.org/10.24843/eJL.2017.v11.i02.p04.

Stecher, B. 2010. Performance Assessment in an Era of Standards-Based Educational Accountability. Stanford, CA: Stanford University, Stanford Center for Opportunity Policy in Education.

Sanford, Daniel. 2014. Bybee's Usage-based Models of Language. In Cognitive Linguistics, edited by Jeannette Littlemore dan John R. Tyalor, 103-116. Bloomsbury, London

Tjendani, E.N. 2016. Classroom Talk as a Classroom Management Practice at Junior High School. $6^{\text {th }}$ ICEMAL Proceedings. Editor Aan Komariah., et.al. P.246-250. Atlantis Press https://doi.org/10.2991/icemal-16.2016.50How to use a DOI? https://www.atlantis-press.com/proceedings/icemal-16/25867374

Tjendani, E.N.2017. Ecolinguistics Approach for English Learning Activities at Junior High School. Article Date Published : 30 August 2017 | Page No.: 3865-3772 | Google Scholar

DOI https://doi.org/10.18535/ijsshi/v4i8.30

https://valleyinternational.net/index.php/theijsshi/article/view/911

Tudor. 2003. Learning to live with complexity: towards an ecological perspective on language teaching_https://doi.org/10.1016/S0346-251X(02)00070-2. Volume 31, Issue 1, March 2003, Pages 1-12 
https://www.sciencedirect.com/science/article/pii/S0346251X02000702

Tomlinson. 2004, Developing Language Course materials, Seameo Regional Language Centre. Singapore

Tomlinson. 2012. Materials Development for Language Learning and Teaching. Cambridge University Press. Cambridge.

Yalden, Janice. 1987. Principles of Course Design for Language Teaching. Cambridge University Press.

Zhang, Jun Lawrence. 2010. The ecology of communicative language teaching: Reflecting on the Singapore experience. https://researchspace.auckland.ac.nz/handle/2292/26201

\section{Acknowledgments}

I would like to express my deep appreciation and thanks to those who have given me hight motivation to finish this work; my nuclear family, parents, and sisters. 